\title{
Allegory of Spiritual Journey to Understand God in Indonesian Novel
}

\author{
Lukman Hanafi ${ }^{1}$ and Joesana Tjahjani ${ }^{2}$ \\ \{90.1hanz@gmail.com ${ }^{1}$, tjahjani.joesana@gmail.com $\left.{ }^{2}\right\}$ \\ ${ }^{1,2}$ Faculty of Humanities, University of Indonesia, Depok 16424, Indonesia
}

\begin{abstract}
Human life has two aspects, which are material and spiritual life. Both aspects have their own characteristics, because material aspect is tangible, but spiritual aspect is intangible. This article analyzes human's spiritual journey to understand God from Indonesian novel. The method used in this article is qualitative with narratology approach, specifically looking at the syntagmatic and paradigmatic relation in the text. The analysis explores structures of text, especially on the fantastic narrative and main characters in the story. Findings of the analysis show that fantastic narrative and main characters interpreted as allegory of human's spiritual journey in understanding God. Based on the context in Indonesia, believeing in God is very important because of the society life is closely related to spiritual or religious aspect. Besides society life, spiritual aspect is very close to personal's life in finding and strengthening the faith. Consequently, the theme of spiritual journey become essential in the life of society in Indonesia.
\end{abstract}

Keywords: allegory; concept of God; fantastic narrative; spiritual journey

\section{INTRODUCTION}

Spiritual journey is a process of every individuals in finding their inner trainquility, until it directs them to understand more about the essence of God. Spiritual aspect of human is perceived as an ability to understand the world and oneself through God-centeredness [1]. Understanding God is an transcendental aspect from human life [2]. In human's spiritual journey to commune with God, an individual finds the concept of God as his hope and assistant. God as the love, as the giver of hope, and as the source of life [3].

Spiritual journey appear in the literature to convey inspirational values. In general, narration about spiritual journey in the literature work pointed out about the transformation of a human being who experience counsciousness about his spiritual aspect. There is the concept of spirituality in the narrative structures which have religious dimension [4]. Meanwhile, there is the theme of spiritual journey that is written in the fantastic narrative through an imaginary characters. Fantastic narrative as a literary genre presents the sudden emerge of a supernatural phenomenon in real world [5].

There are three previous articles that analyze spiritual journey in literature work. It was found the themes about spiritual concept which offered by the narrations. Transformation that experienced by the main character in the novel En Nous la Vie des Morts by Lorette 
Nobécourt is a form of spiritual journey [6]. Analysis in the novel Jane Eyre by Charlotte Brontë found that there is spiritual journey by main character in making her decision to worship God [7]. The agitation on the issues of gender, ethnicity and social norms influence main character's spiritual journey in both novel The Last Report on the Miracles at Little No Horse and Four Souls by Louise Erdrich [8]. In those articles, it is found that spiritual journey appear in realistic narrations, however this analysis discuss about spiritual journey that appear as allegory in the fantastic narrative.

\section{METHOD}

This article is using qualitative method with narratology approach that sees the aspect of syntagmatic and paradigmatic in the text. Syntagmatic and paradigmatic aspect sees the connection on the related elements in narrative structure [9]. In this article, the syntagmatic and paradigmatic relation can be seen in the fantastic narrative and main characters.

The analysis emphasizes on how the fantastic narrative from Indonesian novel titled Semua Ikan di Langit (2017) by Ziggy Zezsyazeoviennazabrizkie interpreted as allegory of human's spiritual journey in understanding God. Allegory shows something and means the other thing, hence there is another side that have hidden meaning and full of puzzles [10]. Besides that, allegory is used as an approach to look for something beyond reach [11].

\section{RESULT AND DISCUSSION}

\subsection{Human nature that appear on the Bus character}

The Bus character was told as an ordinary bus in the narration, it is a land vehicle that carries passenger from one station to another. The Bus that is personified shows that it is not an object, but a real character. With this in mind, the Bus that is personified to be a character and narrator is a metaphor in the story. The Bus can be mean as metaphor of human because it can speak, communicate with the other characters, and it has a life journey. This can be seen from the words by the Bus below.

"Before, one day pass just like this: work, go home, rest, work, go home, rest. Without absent. From early morning, until working hour finished and I, with some people drive together, we finally go home and prepare our self for the similar work next day." [12]

The statement from the Bus shows that it has same activities with human such as work, go home, and rest. Besides that, the time duration in having daily activities from morning to evening shows that there is a reality of human life. This shows that the use of the Bus character is a metaphor from a human being. The Bus that can communicate with other characters through the floor shows a meaning of human behaviour which is curiosity. The utterance by the Bus which can communicate through the floor can be seen in the extract from the novel below.

"As a bus, I hear through the floor. Whoever get in me, step on my floor, tell half of their life, little by little, without they realize." [12]

Based on the extract above, can be seen that the way the Bus communicate is by listening everything around it. The Bus as a narrator in the novel played an important role in narrating every perspective through listening and observation. That is why, the Bus which hears and observes everything around it, is a form of curiosity like human behaviour who has curiosity 
to explore new things around him. This shows that the Bus has human nature, therefore the character represents a human.

\subsection{The almighty God in Beliau}

Beliau has extraordinary capabilities to sew a lot of threads by using his own hand while floating in the sky. Beliau creates many things, from small dolls, huge fabric to sewing vast constellation in the sky. The extraordinary capabilities of Beliau fascinate the Bus because of the miracles that Beliau done. Below is the extract from the novel that shows the capabilities of Beliau.

"However, there is special moment where Beliau moves. It is when Beliau sew. And, there it become: on earth, in the empty sky, there are jumbles of sewing kit, Beliau started to sew." [12]

Beliau who has extraordinary capabilities through sewing many colors of threads in the sky in forming new creation has allegory meaning on the essence of God which has the mightiness to create the life in the universe. Sewing means changing raw material to be another creation, like fabric, decoration, doll, and many creations that made from thread. So, the act of sewing by Beliau in the narrative has allegory meaning about the work of creation, that in the mightiness of God can be mean as a creation of new life.

Besides making miracles by sewing, Beliau did a wonderous action when he cried to fuse the universe that was experiencing turmoil. In the narration, the appearance of turmoil in the universe because of an evil creature who destroyed the universe order. Beliau saw this and he felt in a deep sad, so he started to cry and cry very loud until his tears overwhelm the universe. This can be seen in the extract from the novel below that shows Beliau's action.

"Ah, the kind and sad Beliau. What can I do to stop this cry? The world is stirred by Beliau's tears. Not only the world, but also sky, stars, every space in the sky — dark or bright... All the stories that Beliau told - all his work - was gone swallowed by his cry. This is how it feels like to be broken. So powerful, that all the world broke with you." [12]

The sad tears of Beliau's who can fuse the universe is a form of allegory from the mightiness of God in destroying turmoil life. In this regard, the destroyed life doesn't mean vanishing the universe and there are no life anymore. The mighty of God in destroying this turmoil life is followed by the mightiness of God to recreate a new life. When the life of a star ended, as time goes a new star is born with its new life. Beliau's action by sewing and crying is an allegory from the mightiness of God in organizing the cycle of creation and fusion of the universe. The perfection of the universe represents essence of God, that can be seen in the relation between the Creator, man, and nature [13].

\subsection{Fantastic journey of the Bus is an allegory from human's spiritual journey}

The journey experienced by the Bus, which is flying with fishes that picked it up, is a fantastic journey. The Bus - as a metaphor of human-who experienced an extraordinary journey shows that this is not a physical journey. In this context, the journey experienced by the Bus is not physical activities like work, eat, drink, sleep. The Bus who flew up in the sky shows a meaning that this journey is beyond common physical world. Journey that is beyond physical is out of Bus's control which said in the extract below. 


\begin{abstract}
"I was an ordinary bus. And then, I fly. On that first time, this is what I thought: IF I COULD GO DOWN. BUT I COULD NOT. TRY TO STOP. BUT I COULD NOT. GO TO RIGHT. BUT I COULD NOT.” [12]
\end{abstract}

The journey experienced by the Bus is out of its control. This emphasized that the journey is not a physical journey that is experienced by ordinary human, because daily activities are done in consciousness. Meanwhile, the Bus who experienced the journey by flying out of its control represent not only fantasy, but there is also a supernatural aspect that want to be built in the character. Besides that, the Bus and Beliau have the journey to many places, whether real or imagination. Bus's fantastic journey is out of its control and consciousness, also a journey that does not rely on the dimension of space and time. This fantastic journey means spiritual journey, because spiritual journey does not rely on physical aspect that experienced by human which attached to space and time dimension. Spiritual journey reflected on individual's journey in facing the dynamic of his inner being until he found a mean to believe in God as his highest goal [14].

At the end of this fantastic journey, the feeling of love emerge from the Bus to Beliau. In the beginning, this feeling started from admiration by the mightiness and miracles of Beliau. But throughout their journey, the Bus started to feel deep love towards Beliau.

"Beliau loved me first. And I love Beliau because he loves me that way." [12]

In the extract above, Beliau shows that he was the one who love the Bus first. Beliau who creating life has love to give to every of his creation, including the Bus as a metaphor of human. Throughout their journey, the Bus who cannot understand Beliau directly feel the love through observation and the stories about Beliau. This shows that an individual who is experiencing spiritual journey cannot understand the entire essence of God. The spiritual journey to undesrtand God can lead an individual to feel deep love to God.

In accordance to the analysis above, the fantastic journey that experienced by the Bus have a meaning as allegory of human's spiritual journey to understand God. The allegory that is being used in the narration which have spiritual meaning can reveal profound moral message [15]. In other way, allegory can show the facts about spiritual meaning to human thought [16].

The finding of this exploration about fantastic narrative from novel Semua Ikan di Langit which have an allegory meaning of human's spiritual journey can give impact on the context of society in Indonesia. Believing in God is very important because of the society life is closely related to spiritual or religious aspect. Besides society life, spiritual aspect is very important to personal's life in finding and strengthening the faith. Consequently, the theme of spiritual journey become essential in the life of society in Indonesia.

\title{
4. CONCLUSION
}

The analysis of novel titled Semua Ikan di Langit (2017) by Ziggy Zezsyazeoviennazabrizkie found that the structure of fantastic narrative reveal some findings, that the Bus is a metaphor of human being; Beliau represents the mightiness of God; fantastic journey that is experienced by the Bus and Beliau is an allegory of human's spiritual journey in understanding God.

In the meaning of the Bus as a metaphor of human being, the result of analysis shows that the Bus has the characteristics of human being, such as the activities that it does, its interactions with other characters, its curiosity towards things around it. Therefore, the Bus that reflects human nature can be said that it represents a man. Meanwhile, the character of 
Beliau shows a concept of mightiness of God that is written in the text. The concept of mightiness of God that is written in the text is a mightiness to organize the cycle of creation and fusion of life which is meant for the balance of the universe. Finally, the finding from this analysis revealed that fantastic journey in the narration interpreted as an allegory of human's spiritual journey in understanding God. Spiritual journey to understand God is not enough to be understood entirely, but the process of seeking leads individual to have deeper love to God.

The topic of spiritual journey in understanding and believing God is very essential in the context of society and personal life in Indonesia. The social reality is closely connected to the spiritual aspects, therefore it makes the theme of human's spiritual journey give significant impact to the life of people in Indonesia.

\section{REFERENCES}

[1] C. Wigglesworth, "Spiritual intelligence," in Handbook of Faith and Spirituality in the Workplace: Emerging Research and Practice, 2013.

[2] . B., . I., and M. Yakob, “Transcendental Approach into Danarto's Selected Short Stories," KnE Soc. Sci., 2018.

[3] J.-O. Henriksen, "From Soul to Self," in Relating God and the Self, 2018.

[4] D. Wimayasari, P. K. Hadi2, and Y. Furinawati, "RELIGIUSITAS TOKOH UTAMA DALAM NOVEL SURAT KECIL UNTUK TUHAN KARYA AGNES DAVONAR," Widyabastra J. Ilm. Pembelajaran Bhs. dan Sastra Indones., 2017.

[5] C. B. Harvey, Fantastic transmedia: Narrative, play and memory across science fiction and fantasy storyworlds. 2015.

[6] C. Rodgers, " Flesh Made Word: Spiritual Transformation in the Wilderness in Lorette Nobécourt's En nous la vie des morts ," Roman. Stud., 2013.

[7] K. Sexton, "Jane Eyre : Jane's Spiritual Coming of Age ," Brontë Stud., 2014.

[8] A. M. Genzale, "Medicine Dresses and (Trans)Vestments: Gender Performance and Spiritual Authority in Louise Erdrich's The Last Report on the Miracles at Little No Horse and Four Souls," Crit. - Stud. Contemp. Fict., 2017.

[9] R. Barthes and L. Duisit, "An Introduction to the Structural Analysis of Narrative," New Lit. Hist., 2006.

[10] J. Tambling, "Dante and Benjamin: Melancholy and Allegory," Exemplaria, 2014.

[11] F. Beckman, "Cartographies of ambivalence: allegory and cognitive mapping in Don DeLillo's later novels," Textual Pract., 2018.

[12] Z. Zezsyazeoviennazabrizkie, Semua Ikan di Langit, First. Jakarta: Grasindo, 2017.

[13] T. I. Setyani, "The Manifestation of the Highest God in the Tantu Panggělaran Text: The Perfection of Cosmic Reality," in IOP Conference Series: Earth and Environmental Science, 2018.

[14] A. Adnan, "PERJALANAN ROHANI PERSPEKTIF KAUM SUFI," Syifa al-Qulub, 2018.

[15] A. Gholi and M. A. Mosaabad, "Impediments of Reaching God and Ways of Surmounting Them in Two Selected Allegories of Rumi's Spiritual Couplets," Theory Pract. Lang. Stud., 2014.

[16] K. S. Taghi and K. Rahimzadeh, "The educational approach of allegory in religious texts," Life Sci. J., 2012. 